\title{
Prevalence and risk factors for chronic bronchitis and farmer's lung in French dairy farmers
}

\author{
J C Dalphin, D Debieuvre, D Pernet, M F Maheu, J C Polio, B Toson, A Dubiez, E Monnet, \\ J J Laplante, A Depierre
}

\begin{abstract}
The prevalence of chronic bronchitis and of clinical farmer's lung was studied in $\mathbf{3 0}$ districts of the French Doubs province in relation to individual (age, sex, smoking) and geographical (altitude) factors. 5703 exclusively dairy farmers (response rate $83 \%$ ) participated in the study by answering a medical questionnaire. Prevalences of chronic bronchitis and clinical farmer's lung were $9.3 \%$ and $1.4 \%$ respectively. A logistic regression model was used to evaluate risk factors for chronic bronchitis and clinical farmer's lung. A risk of chronic bronchitis was associated with male sex $\left(p<10^{-4}\right)$, age $\left(p<10^{-4}\right)$, smoker category $\left(p<10^{-4}\right)$, and altitude $\left(p<10^{-4}\right)$. A risk of clinical farmer's lung was associated with non-smokers $(p<0.05)$, and linearly with altitude $\left(p<10^{-4}\right)$. Also there was a strong positive relation between chronic bronchitis and clinical farmer's lung (odds ratio 19.5 $(95 \%$ confidence interval $12 \cdot 1-31 \cdot 4)$ after adjustment for confounding variables. The main finding of this study is the highly significant increase of prevalence of the diseases in relation to altitude.
\end{abstract}

(British Fournal of Industrial Medicine 1993;50:941-944)

Farming is an occupation with one of the highest incidences of respiratory problems. The risks of extrinsic allergic alveolitis and of chronic obstructive lung diseases related to dairy farming have been documented. ${ }^{1}$

The Doubs province is a damp, semimountainous fodder farming region of France in which

\footnotetext{
Department of Respiratory Disease

J C Dalphin, D Debieuvre, D Pernet, M F Maheu,

J C Polio, B Toson, A Dubiez, A Depierre

Department of Epidemiology and Statistics; CHR of Besançon, France

E Monnet

Mutualité Sociale Agricole of the Doubs, Besançon, France

J J Laplante
}

chronic bronchitis ${ }^{2}$ and farmer's lung $^{3}$ are common. The two studies, ${ }^{12}$ which involved dairy farmers in the province, also showed that these respiratory problems were commoner in damp districts located at altitude.

With the cooperation of the Doubs Agricultural Health Insurance Scheme we undertook a screening survey between 1986 and 1991 for chronic bronchitis and farmer's lung in active and exclusively dairy farmers in the province. The results of this survey, which was designed in particular to analyse the influence of individual (age, sex, smoking) and geographic factors on these respiratory problems, are reported here.

\section{Methods}

The Doubs Agricultural Health Insurance Scheme (MSA) organises free routine physical examinations open to all active farmers in the province. The present study took place in the context of the examinations carried out between February 1986 and October 1991, based on a questionnaire.

\section{STUDY POPULATION}

The Doubs province consists of 35 districts. The target population consisted of active dairy farmers in 30 districts. Five districts were not studied (three on the plains and two in the hills) as they are areas of mixed farming not solely based on fodder (cereal and vegetable growing on the plain, forestry and sheep in the hills).

The 30 districts studied had farms that fed only fodder to milk and beef cattle. They covered three zones of progressively increasing altitude from the north west to the south east-namely, plain and foothills (250 to 400 metres altitude), first table land (400 to 750 metres), and second table land (750 to 1000 metres).

The agricultural population of these 30 districts consisted of 7445 active farmers of both sexes. At the time of the study, 6871 farmers were included in the data base of the MSA as potential beneficiaries of free physical examinations. The other 574 farmers were either farmers who did not wish to undergo examinations, young farmers not yet 
included in the data base, or farmers with the possibility of medical monitoring outside MSA schemes. The 6871 farmers were invited to participate in the study by mail; 5703 accepted and answered the questionnaire in full. The response rate was thus $83 \%$ and the cover rate for the total target population was $76 \cdot 6 \%$.

\section{QUESTIONNAIRE}

Farmers received the mailed questionnaire 10 days before their physical examinations. The examination took place close to the home of the farmer and 20 farmers were seen during each half day session. The questionnaire sought information about personal and demographic identification, smoking habits, respiratory history, and respiratory symptoms. Questions about respiratory symptoms were based on the questionnaire of the American Thoracic Society. ${ }^{4}$ Questionnaires were collected during the physical examination and reviewed in the presence of the farmer concerned by the same group of investigator specialists in respiratory diseases throughout the five year period.

Definitions of those symptoms studied in particular were as follows:

Chronic bronchitis-cough and chronic expectoration for three months of the year or more for at least two consecutive years.

Clinical farmer's lung-chronic exposure to (mouldy) fodder stored in barns, at least two episodes during the past two winters combining cough and dyspnoea without wheezing with fever (or symptoms of fever) of delayed (four to 10 hours) onset after handling stored fodder between October and May, and dyspnoea present only or worsening during the winter when livestock were kept inside.

\section{EVALUATION OF SMOKING}

Non-smokers were those who had smoked an average of less than one cigarette or one cigar or one pipe a day for a year. Smokers had smoked this amount or more, whereas ex-smokers had stopped smoking at least a month before the time at which they filled out the questionnaire.

\section{DATA ANALYSIS}

The prevalence of chronic bronchitis and of clinical farmer's lung was calculated with a $95 \%$ confidence interval $(95 \% \mathrm{CI})$.

Individual and geographical risk factors were evaluated by odds ratios and $95 \%$ CIs with a logistic regression model. The frequency of the factors studied was compared in subjects affected by the diseases (chronic bronchitis or clinical farmer's lung) with that in subjects not affected.

BMDP statistical software was used for analysis. A value of $p<5 \%$ was considered significant.

\section{Results}

Table 1 gives a description of the study population

Table 1 Prevalence of chronic bronchitis and clinical farmer's lung related to sex, age, smoking habits, and geography

\begin{tabular}{|c|c|c|c|}
\hline & Population & $\begin{array}{l}\text { Prevalence (\%) of chronic bronchitis } \\
\%(95 \% \text { CI })\end{array}$ & $\begin{array}{l}\text { Prevalence of clinical farmer's lung } \\
\%(95 \% C I)\end{array}$ \\
\hline Total & 5703 & $9 \cdot 3(8 \cdot 5-10)$ & $1.4(1 \cdot 1-1 \cdot 7)$ \\
\hline $\begin{array}{l}\text { Sex: } \\
\text { Women } \\
\text { Men }\end{array}$ & $\begin{array}{l}2657(46 \cdot 6 \%) \\
3046(53 \cdot 4 \%)\end{array}$ & $\begin{array}{c}5 \cdot 5(4 \cdot 6-6 \cdot 4) \\
12 \cdot 7(11 \cdot 5-13 \cdot 9)\end{array}$ & $\begin{array}{l}1.3(0.9-1 \cdot 7) \\
1.5(1 \cdot 1-1.9)\end{array}$ \\
\hline $\begin{array}{l}\text { Age }(y): \\
\quad \text { Mean }(\mathrm{SD}) \\
\quad \text { Range } \\
<30 \\
30-39 \\
40-49 \\
50-59 \\
>59 \\
1.6(0 \cdot 8-2 \cdot 4)\end{array}$ & $\begin{array}{c}47 \cdot 27(12 \cdot 5) \\
15-70 \\
678(11 \cdot 9 \%) \\
931(16 \cdot 3 \%) \\
1184(20 \cdot 8 \%) \\
1842(32 \cdot 3 \%) \\
1068(18 \cdot 7 \%)\end{array}$ & $\begin{array}{c}3 \cdot 2(1 \cdot 9-4 \cdot 5) \\
7 \cdot 4(5 \cdot 7-9 \cdot 1) \\
9 \cdot 5(7 \cdot 8-11 \cdot 2) \\
10 \cdot 4(9-11 \cdot 8) \\
12 \cdot 7(10 \cdot 7-14 \cdot 7)\end{array}$ & $\begin{array}{l}0.6(0.02-1 \cdot 2) \\
1.1(0.4-1 \cdot 8) \\
1.7(1-2 \cdot 4) \\
1.7(1 \cdot 1-2 \cdot 3) \\
1.6(0.8-2 \cdot 4)\end{array}$ \\
\hline $\begin{array}{l}\text { Smoking: } \\
\text { Non-smokers } \\
\text { Ex-smokers } \\
\text { Smokers } \\
\text { Pack-years (SD) }\end{array}$ & $\begin{array}{c}4221(74 \%) \\
539(9 \cdot 5 \%) \\
943(16 \cdot 5 \%) \\
14 \cdot 6(12 \cdot 1)\end{array}$ & $\begin{array}{c}5 \cdot 6(4 \cdot 9-6 \cdot 3) \\
13 \cdot 4(10 \cdot 5-16 \cdot 3) \\
23 \cdot 6(20 \cdot 9-26 \cdot 3)\end{array}$ & $\begin{array}{l}1 \cdot 6(1 \cdot 2-2) \\
2 \cdot 2(1-3 \cdot 4) \\
0 \cdot 4(0-0 \cdot 8)\end{array}$ \\
\hline $\begin{array}{l}\text { Geography: } \\
\text { Plain } \\
\text { Table land } 1 \\
\text { Table land } 2\end{array}$ & $\begin{array}{l}1201(21 \cdot 1 \%) \\
1809(31 \cdot 7 \%) \\
2693(47 \cdot 2 \%)\end{array}$ & $\begin{array}{c}6 \cdot 3(4 \cdot 9-7 \cdot 7) \\
8 \cdot 5(7 \cdot 2-9 \cdot 8) \\
11 \cdot 2(10-12 \cdot 4)\end{array}$ & $\begin{array}{l}0 \cdot 6(0 \cdot 2-1) \\
1 \cdot 1(0 \cdot 6-1 \cdot 6) \\
2 \cdot 1(1 \cdot 6-2 \cdot 6)\end{array}$ \\
\hline
\end{tabular}

^Smokers and ex-smokers. 
Table 2 Adjusted risk of chronic bronchitis and clinical farmer's lung related to sex, age, smoking habits, and geography (logistic regression)

\begin{tabular}{|c|c|c|c|c|}
\hline & \multicolumn{2}{|l|}{ Chronic bronchitis } & \multicolumn{2}{|c|}{ Clinical farmer's lung } \\
\hline & OR $(95 \% C I)$ & p Value & OR $(95 \% C I)$ & p Value \\
\hline $\begin{array}{l}\text { Sex: } \\
\text { Women } \\
\text { Men }\end{array}$ & $1.63(1.3-2.05)$ & $<10^{-4}$ & ${ }_{1.52}^{1}(0.94-2.46)$ & 0.08 \\
\hline $\begin{array}{c}\text { Age (y): } \\
<30 \\
<30-39 \\
40-49 \\
50-59 \\
>59\end{array}$ & $\begin{array}{l}1 \\
2.82(1 \cdot 71-4.65) \\
4.59(2 \cdot 84-7.41) \\
5.46(3.44-8.68) \\
6.35(3.95-10 \cdot 2)\end{array}$ & $<10^{-4}$ & $\begin{array}{l}1 \\
1.84(0.57-5.90) \\
2 \cdot 98(1-8 \cdot 84) \\
2 \cdot 83(0 \cdot 99-8 \cdot 12) \\
2 \cdot 68(0 \cdot 89-8 \cdot 07)\end{array}$ & 0.17 \\
\hline $\begin{array}{l}\text { Smoking: } \\
\text { Non-smokers } \\
\text { Ex-smokers } \\
\text { Smokers }\end{array}$ & $\begin{array}{l}1 \\
1.90(1.40-2.57) \\
5.01(4-6.29)\end{array}$ & $10^{-4}$ & $\begin{array}{l}1 \\
1.08(0.55-2.10) \\
0.23(0.08-0.63)\end{array}$ & 0.016 \\
\hline $\begin{array}{l}\text { Geography: } \\
\text { Plain } \\
\text { Table land } 1 \\
\text { Table land } 2\end{array}$ & $\begin{array}{l}1 \\
1.37(1.02-1 \cdot 84) \\
1.76(1.34-2 \cdot 30)\end{array}$ & $<10^{-4}$ & $\begin{array}{l}1 \\
1.78(0.75-4.25) \\
3.81(1 \cdot 73-8 \cdot 39)\end{array}$ & $10-4$ \\
\hline
\end{tabular}

and of the prevalence of chronic bronchitis and of clinical farmer's lung in the population as a whole $(9.3 \%$ and $1.4 \%$ respectively) and in the various subgroups analysed.

A logistic regression model was used to evaluate risk factors for chronic bronchitis and for clinical farmer's lung (table 2).

A risk of chronic bronchitis was associated with male sex $\left(p<10^{-4}\right)$, age $\left(p<10^{-4}\right)$, smoking category $\left(\mathrm{p}<10^{-4}\right)$, and altitude $\left(\mathrm{p}<10^{-4}\right)$.

A risk of clinical farmer's lung was associated with non-smoker category $(p<0.05)$ and linearly with altitude $\left(p<10^{-4}\right)$.

Also, there was a strong positive relation between chronic bronchitis and clinical farmer's lung. The prevalence of clinical farmer's lung was $8.9 \%$ in farmers with chronic bronchitis and $0.7 \%$ in those free of chronic bronchitis: The odds ratio was 19.5 $(95 \%$ of CI $12 \cdot 1-31 \cdot 4)$ after adjustment for age, sex, smoking, and geography.

\section{Discussion}

The main finding to emerge from this study was the almost linear increase in the risk of chronic bronchitis and farmer's lung with altitude. Furthermore, the classical risk factors for these two diseases were found, notably that of being a non-smoker with regard to farmer's lung.

Two methodological problems should be mentioned before discussing the main finding. Firstly, the response rate; this was satisfactory for a study of this type, but it was not possible to obtain any precise information about respiratory symptoms among non-responders. By contrast, the study population was representative of the target population for sex, age (mean age and age groups), and geo- graphical distribution (source: Espace rural du Doubs (country districts in the Doubs); Direction Départementale de l'Agriculture (Provincial Agriculture Authority)).

Secondly, the definition of farmer's lung; the criteria adopted were strict but only clinical and did not totally ensure the exclusion of organic dust toxic syndrome. ${ }^{5}$ An earlier study on a representative sample of dairy farms in the province showed that insignificant amounts of Gram negative bacteria as a source of endotoxins (the presumed source of organic dust toxic syndrome) were present in the working environment of farmers. ${ }^{6}$ It is likely, therefore, that most of the "clinical farmer's lung" detected was actually farmer's lung. On the other hand, the possibility exists that these criteria might not have detected a certain number of cases of farmer's lung without typical semidelayed symptomatology. It is difficult to use recently recommended paraclinical diagnostic criteria (chest $x$ ray film, respiratory function tests, and possibly indicators of immunisation (precipitins and bronchoalveolar lavages) $)^{7}$ in screening studies of this type, with large populations. This point is further emphasised by the fact that immunological signs are nonspecific and abnormalities of radiological and respiratory function may be transitory ${ }^{89}$ and hence absent when investigations take place outside the acute phase (which is often the case in a cross sectional study)..$^{10}$

The prevalence of chronic bronchitis and of farmer's lung in our population was of the same order as figures previously reported and recently reviewed by Malmberg et $a l^{l}$ The prevalence of chronic bronchitis among dairy farmers ranges from $7 \cdot 6 \%^{11}$ to more than $25 \% .^{12}$ These results depend in particular on the individual (age and sex) 
and occupational characteristics of the populations studied, but above all on smoking habits. In our study, the population contained both sexes, with a low mean age of 47 and with only moderate smoking habits.

Geographical factors seemed to have a fundamental influence on respiratory symptomatology. The type of agricultural activity and the characteristics of farms (size, number of livestock) were similar in the three regions studied. By contrast, it is probable that exposure to organic dust increases in proportion to altitude. Rainfall and dampness increase progressively from the plain to the second table land. Mean annual rainfall, calculated from 1965 to 1985 , ranged from $900 \mathrm{~mm}$ on the plains of the north of the province to $1900 \mathrm{~mm}$ in the higher regions of the second table land (source: Centre Météorologique Départemental (Provincial Meteorological Centre), Besançon). Similarly, the number of days of rain from June to August (haymaking time in our region) also increases proportionally with altitude.

Dampness is the essential factor involved in the growth of thermophilic actinomycetes and moulds in fodder. This could explain the results, in particular for farmer's lung, as reported by other authors. ${ }^{1314}$ The relation between chronic bronchitis and altitude may also be due to increased exposure to organic dust with altitude. It is possible, however, that dampness and cold play a nonspecific part.

The close positive relation between chronic bronchitis and farmer's lung might signify the existence of a common pathophysiological mechanism for these two conditions in a dairy farming context. A case-control study undertaken in the same region showed that farmers with a history of acute respiratory symptoms, in particular semidelayed after exposure to fodder, had an increased risk of developing obstructive chronic bronchitis. ${ }^{15}$

In conclusion, this study provides an estimate of the prevalence of chronic bronchitis and of farmer's lung in a large population of dairy farmers in the Doubs Province. It shows that the risk of chronic bronchitis and of probable farmer's lung increases proportionally with altitude.

Requests for reprints to: J C Dalphin, MD, Department of Respiratory Disease, CHR of Besançon, 2 place St Jacques, 25000 Besançon, France.

1 Malmberg P. Health effects of organic dust exposure in dairy farmers. Am f Ind Med 1990;17:7-15.

2 Dalphin JC, Bildstein F, Pernet D, Dubiez A, Depierre A Prevalence of chronic bronchitis and respiratory function in a group of dairy farmers in the french Doubs province. Chest 1989;95:1244-7.

3 Depierre A, Dalphin JC, Pernet D, Dubiez A, Faucompre C, Breton JL. Epidemiological study of farmer's lung disease in five districts of the french Doubs province. Thorax 1988;43:429-35.

4 Ferris BG. Epidemiology standardization project. Am Rev Respir Dis 1978;119(suppl):7-55.

5 Rask-Andersen A. Organic dust toxic syndrome among farmers. Br F Ind Med 1989;46:233-8.

6 Dalphin JC, Pernet D, Reboux G, et al Influence of mode of storage and drying of fodder on thermophilic actinomycete aerocontamination in dairy farmers on the Doubs region of France. Thorax 1991;46:619-23.

7 Richerson HB, Bernstein IL, Fink JN, et al Guidelines for the clinical evaluation of hypersensitivity pneumonitis. Report of the subcommittee on hypersensitivity pneumonitis. F Allergy Clin Immunol 1989;84:839-44.

8 Emanuel DA, Kryda MJ. Farmer's lung disease. Clin Rev Allergy, 1983;1:509-32.

9 Mönkäre $S$, Ikonen $M$, Haahtela $T$. Radiologic findings in farmer's lung. Prognosis and correlation to lung function. Chest 1985;87:460-6.

10 Dalphin JC, Pernet D, Dubiez A et al. Evaluation de la fiabilité des moyens de détection de la maladie du poumon de fermier. Rev Mal Resp 1989;6:141-5.

11 Terho EO, Husman K, Vohlonen I. Prevalence and incidence of chronic bronchitis and farmer's lung with respect to age, sex, atopy and smoking. Eur $\mathfrak{f}$ Respir Dis (suppl) 1987;152:19-28.

12 Babbott FL, Gump DW, Sylwester DL, MacPherson BV, Holly RC. Respiratory symptoms and lung function in a sample of Vermont dairymen and industrial workers. $A m \mathcal{F}$ Public Health 1990;70:241-5.

13 Terho EO, Heinonen OP, Lammis S. Incidence of farmer's lung leading to hospitalization and its relation to meteorological observations in Finland. Acta Med Scand 1983;213:295-8.

14 Staines FH, Forman JAS. A survey of "farmer's lung". $\mathcal{f}$ Coll Gen Pract 1961;4:351-82.

15 Dalphin JC, Pernet D, Dubiez A, Debieuvre D, Allemand H, Depierre A. Etiological factors of chronic bronchitis in dairy farmers; case control study in the Doubs region of France. Chest 1993 (in press).

Accepted 21 December 1992 